\title{
Determination of tissue thromboplastin activity
}

Citation for published version (APA):

Wijngaards, G., \& Hemker, H. C. (1977). Determination of tissue thromboplastin activity. Haemostasis, 6(2), 89-97. https://doi.org/10.1159/000214168

Document status and date:

Published: 01/01/1977

DOI:

10.1159/000214168

Document Version:

Publisher's PDF, also known as Version of record

\section{Please check the document version of this publication:}

- A submitted manuscript is the version of the article upon submission and before peer-review. There can be important differences between the submitted version and the official published version of record.

People interested in the research are advised to contact the author for the final version of the publication, or visit the DOI to the publisher's website.

- The final author version and the galley proof are versions of the publication after peer review.

- The final published version features the final layout of the paper including the volume, issue and page numbers.

Link to publication

\footnotetext{
General rights rights.

- You may freely distribute the URL identifying the publication in the public portal. please follow below link for the End User Agreement:

www.umlib.nl/taverne-license

Take down policy

If you believe that this document breaches copyright please contact us at:

repository@maastrichtuniversity.nl

providing details and we will investigate your claim.
}

Copyright and moral rights for the publications made accessible in the public portal are retained by the authors and/or other copyright owners and it is a condition of accessing publications that users recognise and abide by the legal requirements associated with these

- Users may download and print one copy of any publication from the public portal for the purpose of private study or research.

- You may not further distribute the material or use it for any profit-making activity or commercial gain

If the publication is distributed under the terms of Article $25 \mathrm{fa}$ of the Dutch Copyright Act, indicated by the "Taverne" license above, 


\title{
Determination of Tissue Thromboplastin Activity
}

\author{
G. WiJngaARds and H.C. Hemker \\ Laboratory of Biochemistry, University of Utrecht, University Centre 'De Uithof', \\ Utrecht; The Netherlands and the Gaubius Institute, Health Research Organization TNO, \\ Leiden, and Department of Biochemistry, State University Limburg, Maastricht
}

Key Words. Tissue thromboplastin · Assay · Prothrombin time test · Factor VII reagent

Abstract. The one-stage prothrombin time test for tissue thromboplastin activity was evaluated using the correction method. A strong influence of the intrinsic system was seen depending on the clotting time and the type of tubes. This test was unsuitable for quantitative comparison of thromboplastin activity of different preparations.

Subsequently a two-stage assay for human thromboplastin is described using purified human factor VII, artificially prepared factor VII reagent, and a phospholipid suspension. The correction method, applicated to this two-stage assay, resulted in a rectilinear doseresponse curve when the clotting times of a thromboplastin dilution series were plotted against the reciprocal of the concentrations.

Using this test system it could be shown that thromboplastin from porcine tissue can activate human factor VII quite well, while that from bovine tissue cannot.

\section{Introduction}

Assays for coagulation factors are based on measuring the coagulation time of a test system in which the factor to be estimated is rate limiting. Since coagulation is dependent upon a sequence of reactions, all factors subsequent to the one being measured must be kept constant or in excess for accurate determinations. For this purpose, plasma from patients with congenital deficiencies or artificially depleted plasmas are used.

In principle, one might use normal plasma in an assay for human tissue thromboplastin activity, because this activity does not occur in plasma. This has been done in a great many studies but there are drawbacks to this method; for example, almost rectilinear plots have often been unjustly claimed to be rectilinear without any theoretical basis and conclusions have been based on this assumption. LITTLE and RATNOFF [1969] concluded from

Received: August 5, 1976; accepted by editor K.LeCHNER: November 20, 1976. 
various plots that no statistical method could be found to compare the activity of different thromboplastin preparations as used in routine tests. In most studies, no attention has been given to the effect of the intrinsic system on the assay and to the effect of the variable lipid content of the sample on the prothrombinase formation. These influences were investigated in more detail in our study. Application of the correction method [HemKer et al., 1965; Hemker and Muller, 1968] showed that the effect of the intrinsic system varied markedly depending on the clotting time, reflecting the thromboplastin activity of the sample. The results of the one-stage prothrombin time test can consequently lead to difficulties in the interpretation and to ambiguous conclusions.

This study deals with a two-stage determination of human thromboplastin activity using purified human factor VII and plasma artificially depleted of factor VII according to LECHNER and DEUTSCH [1967]. The suitability of the assay system to thromboplastin preparations from some other species was studied.

\section{Materials and Methods}

Human brain thromboplastin was prepared from acetone-dried tissue and purified as described by Hecht and OosterbaAN-VAN Lit [1967].

Porcine lung thromboplastin was prepared according to the method of CHARGAFF et al. [1942], with some modifications. Fresh lungs were washed with tapwater, cut into pieces and homogenized in a Waring blender after the addition of saline $(120 \mathrm{ml} / 200 \mathrm{~g}$ tissue). After a period of $3 \mathrm{~h}$ in an ice bath, large particles and connective tissue were removed by centrifugation at $1,250 \mathrm{~g}$ for $10 \mathrm{~min}$. The supernatant was subjected to two successive centrifugations at $2,500 \mathrm{~g}$ for $45 \mathrm{~min}$ and the pellets were discarded. Thromboplastin was sedimented from the final supernatant at $100,000 \mathrm{~g}$ for $60 \mathrm{~min}$. The pellet formed a pinkcoloured lower layer. The upper layer containing most of the thromboplastin activity was removed with a spatula and suspended in about one third of the original volume of borate buffer (I 0.15, pH 8.6) in a Potter-Elvehjem tube. This suspension was subjected to ultracentrifugation $(100,000 \mathrm{~g}$ for $60 \mathrm{~min})$ and resuspension in borate buffer four times. It was subsequently washed four times with distilled water. This resulted in a purified thromboplastin preparation which was free of soluble proteins. The grey-coloured pellet was lyophilized and stored at $-20^{\circ} \mathrm{C}$.

Bovine brain thromboplastin prepared from fresh tissue as described by OWREN and Aas [1951] was used.

Phospholipid suspension. A petroleum ether extract of acetone-dried human brain tissue [FISCHER and НесHT, 1934] was evaporated under reduced pressure and the lipids were dissolved in diethyl ether $(1 \mathrm{ml} / 10 \mathrm{mg}$ lipid). The solution obtained was added dropwise to stirred veronal-acetate buffer (I $0.15, \mathrm{pH} 7.4)$ through which nitrogen was blown. The suspension, containing $1.0 \mathrm{mg} \mathrm{lipid} / \mathrm{ml}$, was stored in $1-\mathrm{ml}$ portions in plastic tubes at $-20^{\circ} \mathrm{C}$. 
Normal platelet-poor plasma was obtained from human blood collected from a number of healthy individuals into siliconized tubes containing one tenth of the blood volume of $0.112 \mathrm{M}$ sodium citrate by centrifugation at $15,000 \mathrm{~g}$ for $30 \mathrm{~min}$. The plasma was stored in plastic tubes at $-80{ }^{\circ} \mathrm{C}$.

Factor VII reagent was prepared from fractions of human-citrated plasma and bovineoxalated plasma according to the modified method of LECHNER and Deutsch [1967] as described by Hemker et al. [1972].

Factor $X$ was measured using artificially depleted plasma prepared by the method of HEMKer et al. [1972].

Human factor VII was purified by using several purification techniques as described by SwART [1971]. The initial fractions of the DEAE-cellulose column in the factor VII reagent preparation were used as a source for factor VII. After adsorbtion to aluminium hydroxide ('moist gel', BDH) $(0.5 \% \mathrm{w} / \mathrm{v})$ at $4{ }^{\circ} \mathrm{C}$, the adsorbent was washed with $0.3 \mathrm{M}$ sodium EDTA, $\mathrm{pH} 8.0$, and $0.1 \mathrm{M}$ sodium citrate, $\mathrm{pH} 8.0$, followed by elution of factor VII by $0.25 \mathrm{M}$ phosphate buffer, $\mathrm{pH}$ 8.0. The eluate was subjected to ammonium sulphate precipitation. Factor VII was almost completely precipitated between 40 and $60 \%$ saturation at $4{ }^{\circ} \mathrm{C}$. After centrifugation at $20,000 \mathrm{~g}$ for $60 \mathrm{~min}$, the pellet was dissolved in distilled water and applied to a Sephadex G-100 column $(95 \times 2.5 \mathrm{~cm})$. The column was eluted with $0.02 \mathrm{M}$ phosphate buffer, $\mathrm{pH} 6.8$, to which $0.1 \mathrm{M} \mathrm{NaCl}$ had been added. The factor VII peak was situated just after a small peak containing factor $\mathrm{X}$. The fractions were combined and dialyzed against veronal-chloride buffer (I 0.015, pH 7.35) for $18 \mathrm{~h}$. The activity of the factor VII preparation was adjusted to $40 \%$ of that of normal plasma. The factor X activity of this preparation usually did not exceed $2 \%$ of that in normal plasma. The preparation was stored in $1-\mathrm{ml}$ portions in plastic tubes at $-80^{\circ} \mathrm{C}$.

One-stage prothrombin time test. To $0.1 \mathrm{ml}$ of human platelet-poor plasma, $0.1 \mathrm{ml}$ of thromboplastin suspension was added. After $30 \mathrm{sec}$ incubation at $37^{\circ} \mathrm{C}$, the mixture was recalcified with $0.1 \mathrm{ml}$ of $0.025 \mathrm{M}$ calcium chloride and the time necessary for clotting was measured with a chronometer. The test was performed in glass tubes as well as in polysterol tubes. The effect of phospholipids in this test was investigated by adding $0.1 \mathrm{ml}$ of phospholipid suspension $(0.3 \mathrm{mg} / \mathrm{ml})$ to the plasma followed by $0.1 \mathrm{ml}$ of thromboplastin and recalcification with $0.1 \mathrm{ml}$ of $0.033 \mathrm{M}$ calcium chloride.

Two-stage assay of thromboplastin. Factor VII preparation $(0.1 \mathrm{ml})$, thromboplastin suspension $(0.1 \mathrm{ml})$ and $0.075 \mathrm{M} \mathrm{CaCl}_{2}$ solution $(0.1 \mathrm{ml})$ were mixed and incubated for $15 \mathrm{sec}$ at $37^{\circ} \mathrm{C}$. Following this, $0.1 \mathrm{ml}$ of this mixture was added to a mixture of factor VII reagent $(0.1 \mathrm{ml})$ and phospholipid suspension $(0.1 \mathrm{ml}$ with optimal concentration) preheated for about $30 \mathrm{sec}$ at $37^{\circ} \mathrm{C}$ and the clot formation was timed. Both stages were performed in glass tubes and the clotting was determined with a Kolle hook. The optimal concentration of the phospholipid suspension was estimated in a similar two-stage assay, except that the thromboplastin suspension was replaced by Russell viper venom $(0.1 \mathrm{mg}$ ) $\mathrm{ml}$ distilled water).

The correction method of HEMKER et al. for the assays of extrinsic coagulation factors permits the calculation of the residual amount of an extrinsic factor in its test reagent by using a one-stage procedure [HemKer et al., 1965; HeMKer and Muller, 1968]. If a series of known concentrations, c, of a factor is tested in a one-stage assay for that factor, a number of clotting times, $t_{c}$, is obtained. Using buffer as a sample will give the buffer time, $t_{b}$, of the test medium. If this buffer time is assumed to be due to an unknown but constant 
amount, L, of the rate-limiting factor in the reagent, and Michaelis-Menten kinetics apply, then a rectilinear relationship should exist between $\left(t_{b}-t_{c}\right) / c$ and $t_{c}$. This is indeed found with one-stage assays in the extrinsic system. This graph is known as the correction plot, as the slope of the curve allows the expression of the quantity $\mathrm{L}$ in the same units as $\mathrm{c}$. Correction of $\mathrm{c}$ for $\mathrm{L}$ then produces a straight line relationship between $\mathrm{t}_{\mathrm{c}}$ and the inverse of the total concentration of the coagulation factor. With the aid of this curve and the clotting times of samples, the concentrations can be calculated more accurately than with the plotting of $\mathrm{c}$ versus $\mathrm{t}_{\mathrm{c}}$ on double logarithmic paper.

\section{Results}

Application of the correction method described by HEMKER and associates [HeMKer et al., 1965; HeMKer and Muller, 1968] to the clotting times of a series of dilutions of tissue thromboplastin in the one-stage prothrombin time test performed in glass tubes did not result in a rectilinear correction plot (fig. 1, curve A). So, besides the clotting initiated by the thromboplastin, there was an additional influence on the clotting process which varied depending on the clotting time. Inclusion of additional phospholipid so as to prevent prothrombinase formation from being a possibly limiting step at low thromboplastin concentrations had no effect on the observed nonlinearity (fig. 1, curve B). Replacement of the glass tubes by polysterol ones resulted in a less curvilinear relation at least over a certain dose-response range (fig. 2). Addition of phospholipid to these tubes also led to no improvement. We concluded that the intrinsic system has a disturbing effect on the estimation of thromboplastin activity in the one-stage prothrombin time test. In a limited range, the correction plot can be used for practical purposes; however, the value of $\mathrm{L}$ obtained should be interpreted with caution.

A series of dilutions of tissue thromboplastin in the two-stage assay at a phospholipid concentration for optimal clotting $(0.3 \mathrm{mg} / \mathrm{ml})$ (fig. 3) did result in a rectilinear correction plot (fig. 4 , curve A), indicating the occurrence of a constant activity, $\mathrm{L}$, in addition to that of thromboplastin. This activity of the test system was found to correspond to $0.038 \mathrm{mg} / \mathrm{ml}$ of the thromboplastin preparation used. Plotting of the clotting times against the reciprocal of the total concentration $(\mathrm{TP}+\mathrm{L}$ ) produced a rectilinear doseresponse curve for this two-stage assay of tissue thromboplastin (fig.5, curve A).

Plotting of clotting times versus thromboplastin concentrations on double logarithmic paper resulted in a diagram which was approximately rectilinear as can be shown by a statistical analysis. In practice, this curve may be used 


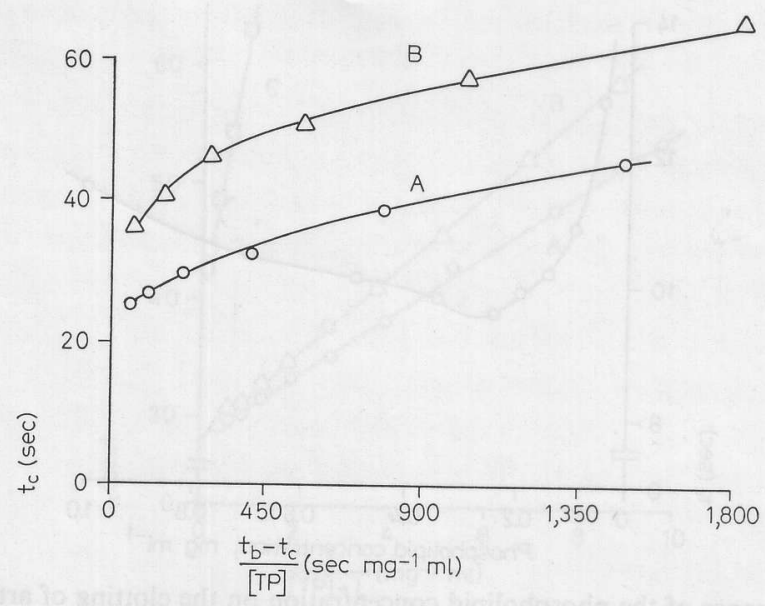

Fig.1. Correction plot for the one-stage prothrombin time test with human plateletpoor plasma and porcine lung thromboplastin in glass tubes. Curve A: $0.1 \mathrm{ml}$ plasma, $0.1 \mathrm{ml}$ thromboplastin and $0.1 \mathrm{ml} 0.025 \mathrm{M}$ calcium chloride; curve B: $0.1 \mathrm{ml}$ plasma, $0.1 \mathrm{ml}$ phospholipid suspension, $0.1 \mathrm{ml}$ thromboplastin and $0.1 \mathrm{ml} 0.033 \mathrm{M}$ calcium chloride.

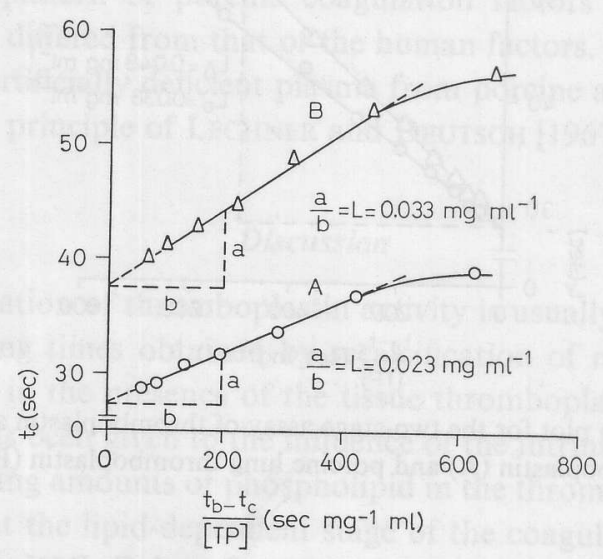

Fig. 2. Correction plot for the one-stage prothrombin time test with human plateletpoor plasma and porcine lung thromboplastin in polysterol tubes. Other conditions as in figure 1.

but then the inaccuracy in the determination of low thromboplastin activities is increased.

The usefulness of this test system in studies on thromboplastin preparations from other species was tested on porcine and bovine thromboplastin. 


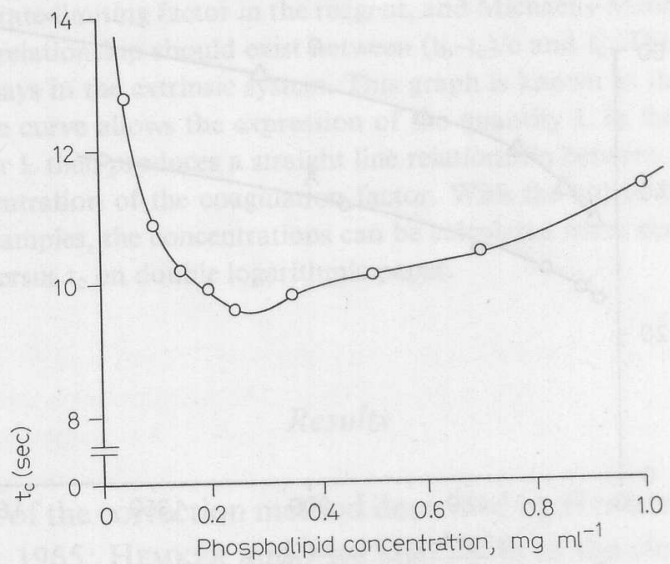

Fig.3. Influence of the phospholipid concentration on the clotting of artificially made factor VII deficient plasma by Russell viper venom.

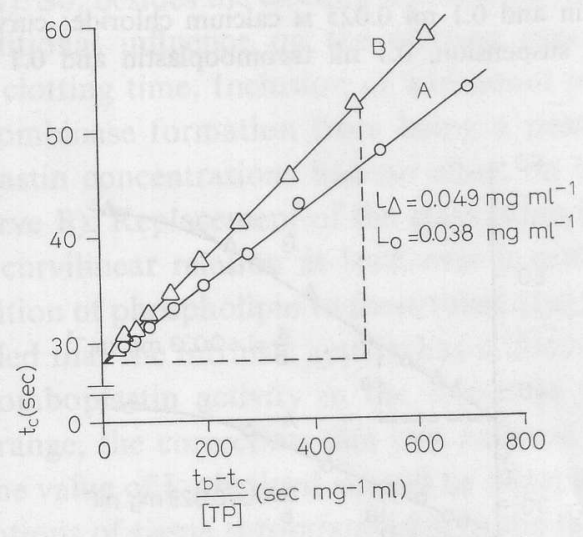

Fig.4. Correction plot for the two-stage assay of thromboplastin activity with purified human brain thromboplastin (A) and porcine lung thromboplastin (B).

The results are given in figure 5, curves B and C. Bovine brain thromboplastin, highly active when tested with bovine plasma, demonstrated only a small amount of activity, whereas porcine lung thromboplastin activated human factor VII quite reasonably. By taking the activity of the homologous human brain thromboplastin as $100 \%$, the activity of the porcine preparation was $75 \%$ and that of the bovine preparation only $4 \%$ on a weight basis. These differences must be attributed to species specificity and to the actual thromboplastin content of the preparations. 


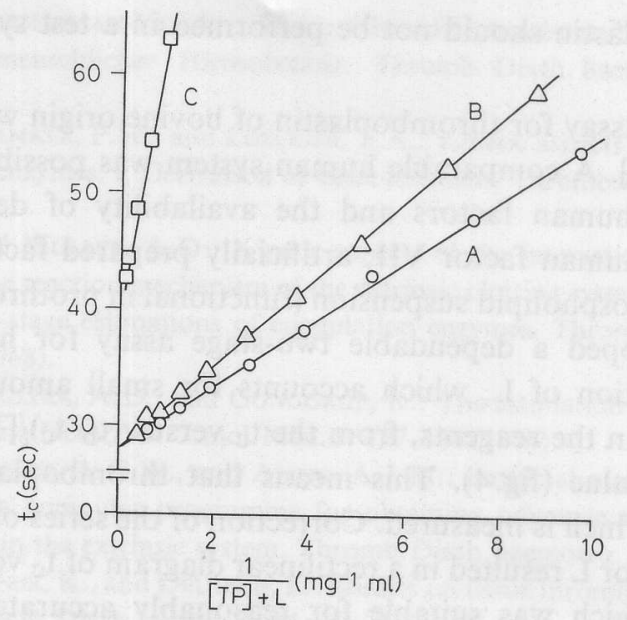

Fig. 5. The relationship between coagulation time $\left(t_{c}\right)$ and concentration of thromboplastin in the two-stage assay after correction. $\mathrm{A}=$ purified human brain thromboplastin; $\mathbf{B}=$ purified porcine lung thromboplastin; $\mathrm{C}=$ bovine brain thromboplastin.

The elution pattern of porcine coagulation factors VII and II from DEAE-cellulose differed from that of the human factors. Consequently, the preparation of artificially deficient plasma from porcine and bovine plasma according to the principle of LECHNER and DeUTSCH [1967] did not succeed.

\section{Discussion}

The determination of thromboplastin activity is usually based on a comparison of clotting times obtained by recalcification of normal citrated or oxalated plasma in the presence of the tissue thromboplastin preparations. Less attention has been given to the influence of the intrinsic pathway or the effect of the varying amounts of phospholipid in the thromboplastin samples which function at the lipid-dependent stage of the coagulation mechanism.

Kinetic studies [Hemker et al., 1965; HemKer and Muller, 1968] made possible the evaluation of this assay system. A very strong influence of the intrinsic system was found when the test system was carried out in glass tubes; it played a less pronounced role in polysterol tubes. Effects due to dilution of the phospholipid in a series of dilutions of thromboplastin were eliminated by adding a constant amount of phospholipid suspension to the assay system. However, this inclusion did not result in an improvement of the linearity of the dose-response curve. Consequently, the determination of 
tissue thromboplastin should not be performed in a test system containing normal plasma.

A two-stage assay for thromboplastin of bovine origin was developed by NeMERSON [1968]. A comparable human system was possible only with the purification of human factors and the availability of deficient plasmas. Using purified human factor VII, artificially prepared factor VII deficient plasma and a phospholipid suspension (functional in prothrombinase formation), we developed a dependable two-stage assay for human thromboplastin. Calculation of $\mathrm{L}$, which accounts for small amounts of clot-promoting activity in the reagents, from the $t_{c}$ versus $\left(t_{b}-t_{c}\right) /[T P]$ plot resulted in a constant value (fig. 4). This means that thromboplastin is the ratelimiting factor which is measured. Correction of the series of thromboplastin concentrations for $\mathrm{L}$ resulted in a rectilinear diagram of $\mathrm{t}_{\mathrm{c}}$ versus $1 /([\mathrm{TP}]+\mathrm{L})$ with a slope which was suitable for reasonably accurate comparison of thromboplastin activities (fig. 5). In addition, these results confirm the indication obtained by HEMKER and MULLER [1968] that tissue thromboplastin behaves like the other coagulation factors of the extrinsic system. Variation of the incubation time in the first stage of this assay between 15 and $60 \mathrm{sec}$ did not influence the clotting time. This suggests that no reaction took place in the first stage or that it was completed within $15 \mathrm{sec}$. According to observations of WILLIAMS and NORRIS [1966] and NEMERSON [1966], a rapid reaction is indeed probable.

Equal amounts of porcine and bovine thromboplastin preparations revealed that the porcine preparation can activate human factor VII quite well, while the bovine preparation cannot (fig. 5). This differing capacity of thromboplastin preparations to activate human factor VII owing to species specificity [QUick, 1941; Soldati, 1941; MANN and HURN, 1952; STORMORKEN, 1957; IRSIGLER et al., 1965] can be expressed more quantitatively by using this test system. The inefficiency of bovine thromboplastin in the activation of human factor VII and its high sensitivity towards activated human factor VII [LAAKE and ELLINGSEN, 1974] have been applied in the estimation of human factor VII activated by incubation in the cold [HEMKER et al., 1976].

\section{References}

Chargaff, E.; Moore, D.H., and Bendich, A.: Ultracentrifugal isolation from lung tissue of a macromolecular protein component with thromboplastic properties. J.biol. Chem. 145: 593-603 (1942).

FisCHER, A. und HeCHT, E.: Über die chemische Natur des Lipoidfaktors bei der Blutgerinnung. Biochem.Z.269: 115-132 (1934). 
Hecht, E. und OosterbaAn-Van Lit, W.L.: Über die chemische Natur des Thromboplastins aus menschlicher Hirnsubstanz. Thromb. Diath. haemorrh. 18: 223-240 (1967).

Hemker, H.C.; Hemker, P.W., and Loeliger, E.A.: Kinetic aspects of the interaction of blood clotting enzymes. I. Derivation of basic formulas. Thromb. Diath. haemorrh. 13: 155-175 (1965).

Hemker, H.C. and Muller, A.D.: Kinetic aspects of the interaction of blood clotting enzymes. V. The reaction mechanism of the extrinsic clotting system as revealed by the kinetics of one-stage estimations of coagulation enzymes. Thromb. Diath.haemorrh. 19: 368-382 (1968).

HemKer, H.C.; Muller, A.D., and GongGriJP, R.: The estimation of activated human blood coagulation factor VII. J.mol. Med. 1: 127-134 (1976).

Hemker, H.C.; Swart, A.C.W., and Alink, A.J. M.: Artificial reagents for factor VII and factor $\mathrm{X}$, a computer programme for obtaining reference tables for one-stage determinations in the extrinsic system. Thromb. Diath. haemorrh. 27: 205-211 (1972).

Irsigler, K.; LeChNer, K., and DeuTsch, E.: Studies on tissue thromboplastin. II. Species specificity. Thromb. Diath. haemorrh. 14: 18-31 (1965).

LAake, K. and Ellingsen, R.: Purification and some characteristics of factor VII in human citrated plasma, glass-activated serum, and cold-activated plasma. Thromb. Res. 5: 539-556 (1974).

Lechner, K. und Deutsch, E.: Eine einfache Methode zur Herstellung von menschlichem Faktor-VII-Mangelplasma. Thromb. Diath. haemorrh. 18: 252-258 (1967).

LitTLE, A.S. and RatNoFF, O.D.: A comparative study of several thromboplastins used to measure the one-stage prothrombin time. Thromb. Diath. haemorrh. 35: suppl., pp. 135-146 (1969).

MANN, F.D. and HuRn, M.M.: Species specificity of thromboplastin. Role of the cothromboplastin reaction. Proc. Soc. exp. Biol. Med. 79: 19-21 (1952).

Nemerson, Y.: The reaction between bovine brain tissue factor and factors VII and X. Biochemistry 5: 601-608 (1966).

Nemerson, Y.: The phospholipid requirement of tissue factor in blood coagulation. J. clin. Invest. 47: 72-80 (1968).

OWREN, P.A. and AAS, K.: Control of dicoumarol therapy and the quantitative determination of prothrombin and proconvertin. Scand. J.clin. Lab. Invest. 3: 201-208 (1951).

QUick, A.J.: The prothrombin concentration in the blood of various species. Am.J. Physiol. 132: 239-244 (1941).

SoldatI, B.: Untersuchungen über Thrombokinase. Ihre Bedeutung für die Prothrombinzeitbestimmung; Thesis Zürich (1941).

Stormorken, H.: Species differences of clotting factors in ox, dog, horse and man. Thromboplastin and proconvertin. Acta physiol.scand. 41: 301-324 (1957).

Swart, A.C.W.: Studies on the purification and separation of blood coagulation factors II, VII, IX and X; Thesis Leiden (1971).

WILlIAMS, W.J. and NORRIS, D.G.: Purification of a bovine plasma protein (factor VII) which is required for the activity of lung microsomes in blood coagulation. J.biol. Chem. 241: 1847-1856 (1966).

Dr. G. WiJNGAARDS, Gaubius Institute, Health Research Organization TNO, Herenstraat 5d, Leiden (The Netherlands) 